\title{
A Review of Child Sexual Abuse in Pakistan Based on Data from "Sahil" Organization
}

\author{
Muhammad Abdullah Avais ${ }^{1}$, Hamida Narijo ${ }^{2}$, Mike Parker \\ 1 Ph.D. Scholar, Department of Sociology, University of Sindh Jamshoro, Pakistan \\ ${ }^{3}$ Assistant Professor, Department of Sociology, University of Sindh Jamshoro, Pakistan \\ ${ }^{3}$ Medical Statistician
}

\begin{abstract}
A B S TRACT
Child sexual abuse (CSA) is an unrevealed but an alarming issue in every civilized society. This paper examines the reported incidents of child sexual abuse in Pakistan. Its primary goal is to assess the currently available data on incidents of CSA in Pakistan from 2010 to 2016, while the specific objective is to understand the magnitude, as well as nature and context of the problem. Data on CSA from 2010 to 2016 were collected from the "annual cruel numbers" of the "Sahil" organization, which revealed that incidents of CSA have increased in Pakistan since 2010. The data show that 2,252 incidents of CSA (Boys 606 and Girls 1,646) occurred in 2010 and a larger number, 4,139 incidents (Boys 1,729 and Girls $2,410)$, occurred in 2016. Most of the survivors belonged to the Punjab province of Pakistan (1,723 out of 2,252 in 2010 and 2,676 out of 4,139 in 2016). Most abusers were acquaintances of their victims (3,964 in 2010 and 1,829 in 2016). The majority of incest cases were observed in 2012 (144 cases). The victim's home was a place of abuse in most incidents (306 incidents in 2010 and 594 in 2016). Government, as well as non-governmental organizations, should raise awareness of CSA. Furthermore, religious leaders must play their role to curb occurrence of CSA by preaching about its religious implications.
\end{abstract}

Key words: Children, Incest, Incidents, Pakistan, Sahil organization, Sexual victimization

\begin{tabular}{|c|c|c|}
\hline Authors' Contribution: & Correspondence: & Article info: \\
\hline${ }^{1-3}$ Conception; Literature search; & Muhammad Abdullah Avais & Received: October 5,20 \\
\hline $\begin{array}{l}\text { Manuscript design and drafting; Critical } \\
\text { analysis and Manuscript review; Manuscript } \\
\text { editing. }\end{array}$ & Email:abdullahawais77@yahoo.com & Accepted: September 25 \\
\hline
\end{tabular}

Doi: 10.35787/jimdc.v9i3.412

\section{Introduction}

Half of the children across the world are exposed to violence every year. ${ }^{1}$ The culprit's violence and survivor's trauma, along with its consequences, are commonly obscured from the public view. ${ }^{2}$ Child sexual abuse (CSA) is an unrevealed but an alarming issue in every civilized society. ${ }^{3}$ In this era of globalization, there is a need for designating time to educate and empower the most vulnerable in society against abuse from strangers and their teachers and relatives. ${ }^{4}$ The frequency of such offenses are increasing. There are daily reports, in either local or national newspapers, about different types of child abuse. Some of these stories seem 
improbable because of the cruelty and inhumane torture described. It can seem unbelievable that some fathers are found to be involved in abusing their own children, that teachers harass their students, that women batter boys, and that employees try to hire uneducated, unskilled young children below the age of maturity. These types of child abuse have not been reported for multiple reasons, such as family pressure, poverty, negligence of parents, social barriers, and political influence of offenders. ${ }^{5,6}$ South Asia has $23 \%$ of the world's population and is also known as the world's most impoverished region. In many countries of South Asia, such as Pakistan, India, Bhutan, Nepal, and Bangladesh, child labor, child trafficking, child prostitution, and child sexual abuse are common problems. $^{7}$

There are many forms of violence against children; psychological, sexual, emotional, and physical abuse. Physical anger directed towards a child by an adult is an example of physical abuse. ${ }^{8}$ Child sexual abuse (CSA) is a form of child abuse in which an adult or older adolescent sexually stimulates a child. ${ }^{9}$ Child sexual abuse consists of different forms, such as forcing a child to be engaged in sexual activities, showing pornographic material to a child, sexual intercourse/attempted intercourse with a child, viewing of the child's genitalia with or without physical contact, or using a child for prostitution or pornography. ${ }^{8-10}$

In 2011, 50 police officials were found to be perpetrators of CSA in Pakistan, and 10 of them used official residential quarters of police for their offenses. Similarly, 155 officials were involved in CSA in 2012, and 13 cases were committed in police stations, with five children being sexually abused in police lockups in 2013. ${ }^{11}$ Depression, unemployment, physical and mental illness, poor socialization or trouble in socialization are common factors seen in perpetrators. ${ }^{12-14}$ Different taboos such as the claimed curative powers of virgins are often reasons stated or believed by perpetrators for the CSA. ${ }^{13,15,16}$

This paper examines the reported incidents of child sexual abuse in Pakistan. Its primary goal is to assess the currently available data on incidents of CSA in Pakistan from 2010 to 2016, while the specific objective is to understand the magnitude, as well as nature and context of the problem. The research employs an exploratory approach using secondary data. The data for CSA from 2010 to 2016 were obtained from "Sahil" organization, a nongovernmental organization working on creating a society free from all forms of violence, especially child sexual abuse. The Sahil organization is functional through its head office in Islamabad, the capital of Pakistan and has four regional offices. Through the monitoring of 91 local and national newspapers at its head and regional offices, along with help from volunteers, the organization collects the data of CSA on an annual basis and, after compilation at its head office, Sahil publishes a report on "cruel numbers" on an yearly basis.

\section{Discussion}

According to the World Health Organization (2006), CSA is "the involvement of a child in sexual activity that he or she does not fully comprehend, is unable to give informed consent to, or for which the child is not developmentally prepared, or else that violates the laws or social taboos of society. ${ }^{132}$ Commonly, the perpetrators of sexual abuse are predominantly male. ${ }^{33}$

In 2006, a report on the prostitution of Pakistani boys at Lahore and Peshawar recognized that society strongly condemned the relationship between a male and female without marriage, while affection between males, either social or physical, was socially tolerated. ${ }^{34}$ There are no accurate statistics regarding CSA in Pakistan, but it is estimated that sexual abuse mostly affects girls 
(19\%) compared to boys (14\%). ${ }^{35}$ In India, $52 \%$ of school-going children were sexually abused, and $89 \%$ of perpetrators were family members. ${ }^{36,37}$ In 2017, Sahil NGO computed 3445 cases of CSA from 91 national and local Pakistani newspapers. ${ }^{38}$ In Rawalpindi/Islamabad, $17 \%$ of 300 school-going children were survivors of CSA ( 1 in 7 girls and 1 in 5 boys), and the majority of victims (72\%) were below the age of 13 years. ${ }^{38}$ Close acquaintances of the victims were found to be involved in $80 \%$ of CSA cases. ${ }^{39,40}$ Across the globe, regardless of religion and culture, $40-60 \%$ of known sexual assaults were committed by family members, and the victims were girls belonging to the age group 15 years or younger. ${ }^{41}$

In Pakistan, like other South Asian countries, Child mobility, poverty, inadequate education, weak rule of law, and child labor are common factors behind the CSA or child exploitation. ${ }^{42}$

Child sexual abuse is probably a less acknowledged and less explored form of abuse in Pakistan because people hesitate to open a Pandora's Box of problems. Nevertheless, child sexual abuse has been present in Pakistan since the date of its national independence since 1947. These incidents produce long-lasting effects on both society and victims. Although child sexual abuse exists in Pakistani society, it is nevertheless a taboo subject. In Pakistan, it is easy to talk about sex, but talking about sexuality is regarded as immoral. The number of survivors of CSA is increasing day by day, and from January 2010 to December 2016, a total of 21,760 cases of CSA were reported.

The number of reported incidents of Child Sexual Abuse in Pakistan from 2010 to 2016 showed an upward trend with increase in number of cases from 2010 to 2016 (Figure 1). The number of cases in the year 2010 was 2,252, with 2,303 incidents reported in 2011, 2,788 incidents in 2012, 3,002 incidents in
$2013,3,508$ incidents in $2014,3,768$ incidents in 2015, and 4,139 incidents in 2016.

The gender-specific distribution of reported cases of CSA from 2010 to 2016 is shown in Figure 2. The number of abused girls was approximately 2.5 times more than boys from 2010 to 2013, however the number of boys increased steadily from 2014 to 2016.

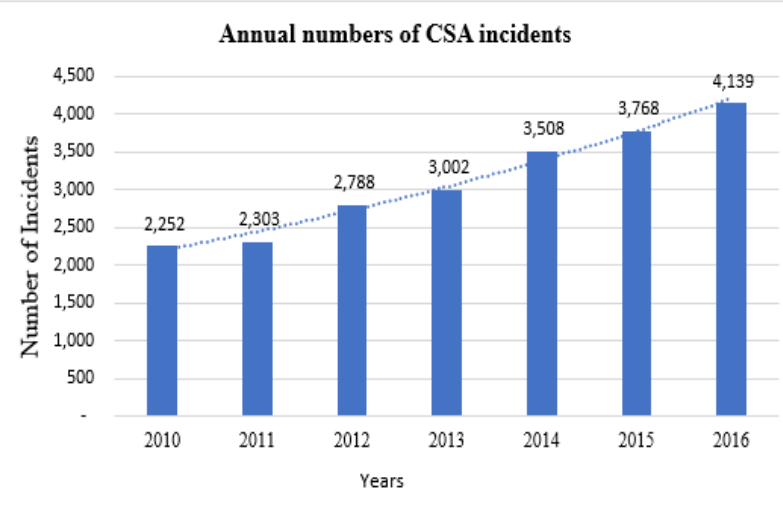

Figure 1: Number of CSA incidents from 2010 to 2016

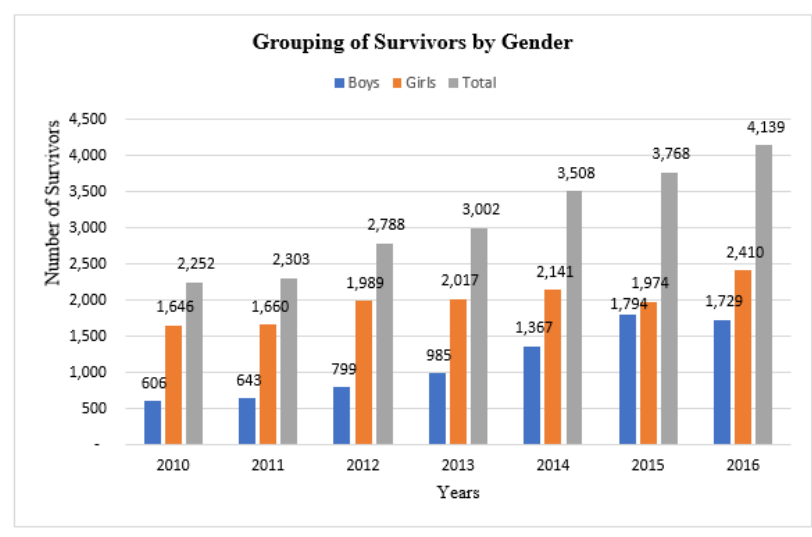

Figure 2: Grouping of survivors by gender

Figure 3 shows the distribution of incidents of CSA by province, with the majority of cases taking place in Punjab. The actual figure may be higher than those reported since, due to honor and to avoid defaming a whole family, parents try not to share the incident with anyone. Therefore, sometimes they blame the survivors. Similarly, due to fear, sometimes survivors do not share the details of incidents with their parents, so these cases go 
unreported. These figures are indicative of the values of any civilized society.

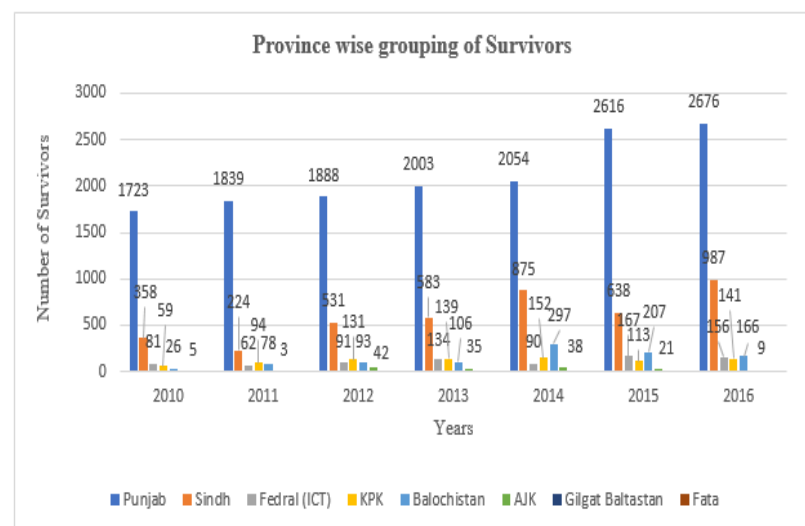

Figure 3: Province wise distribution of survivors

Althugh most of CSA cases were register with the police, it failed to decrease the number of cases reported annually (Figure 4). Incidents occurred at victims' homes, with nearly as many incidents occurring at acquaintances' homes also (Table I).

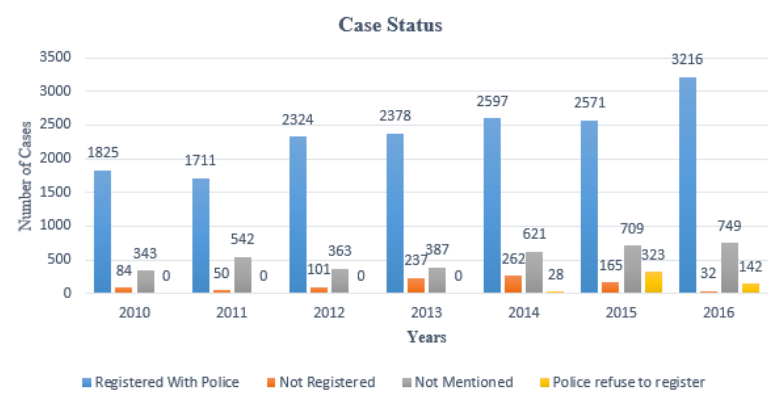

Figure 4: Status of Police registration of sexual abuse cases

Table II is presenting the abuser profiles. Majority of abusers were acquaintances, with strangers being in a close second place. Compared to strangers, most perpetrators are known to their victims or at least to relatives of the survivors. ${ }^{43}$

The issue of CSA must be addressed as a priority by religious leaders, parents, civil society, policymakers, law enforcement agencies, and social scientists. Moreover, the outcome of different NGOs working on child rights and awareness of CSA needs to be evaluated by concerned authorities. The major determinants of CSA in Pakistan are poverty, illiteracy, and various unacceptable taboos regarding sexual health. The government should provide basic health needs and education to all children. In addition to this, it is the prime duty of the government to raise awareness in law enforcement agencies on how to address victims of CSA. Sahil collects CSA data from a compilation of 84 national and local newspapers, which may not represent the magnitude of severity. Thus, the government must collect the data of survivors of CSA at the national level for policymakers and social scientists, because NGOs cannot engage in this role as effectively as government agencies. Furthermore, the government should develop a national action plan against child sexual abuse/exploitation.

Limitation: This study was solely based on a secondary source of data collected from the "Cruel Numbers" of Sahil organization from 2010 to 2016, therefore, some data may be missing because of not ever being reported to the Sahil organization.

\section{Conclusion}

In Pakistan, children are exposed to sexual abuse everywhere-in markets, at schools, in hospitals/clinics, at madrasa and police stations, and even their own homes. The analysis of the data demonstrated that the number of CSA cases was increasing gradually year by year in Pakistan. Although some NGOs are working to raise awareness of CSA in society, the topic of CSA remains a taboo subject for discussion in Pakistan.

\section{Recommendations}

- Government, civil society, and religious leaders should recognize CSA as a major threat to the fabric of society, that is intolerable at any cost. Therefore, the government should address this issue as a crime against humanity at the national level. 
- The increasing incidents of CSA are questioning the prestige of the traditional and religious family system in Pakistan. Policymakers, sociologists, and criminologists should seriously take up this

\begin{tabular}{|l|c|c|c|c|c|c|c|c|}
\hline \multicolumn{7}{|c|}{ Table I: Yearly distribution of cases according to probable location for sexual abuse } \\
\hline \multirow{2}{*}{ Place of Incident } & $\mathbf{2 0 1 0}$ & $\mathbf{2 0 1 1}$ & $\mathbf{2 0 1 2}$ & $\mathbf{2 0 1 3}$ & $\mathbf{2 0 1 4}$ & $\mathbf{2 0 1 5}$ & $\mathbf{2 0 1 6}$ \\
\cline { 2 - 9 } Number of Incidents n (\%) \\
\hline Victim's home & $306(7.6)$ & $1042(26.0)$ & $566(14.1)$ & $492(12.3)$ & $475(11.8)$ & $539(13.4)$ & $594(14.8)$ \\
\hline $\begin{array}{l}\text { Acquaintance's } \\
\text { home }\end{array}$ & $369(8.4)$ & $809(18.5)$ & $648(14.8)$ & $630(14.4)$ & $653(14.9)$ & $689(15.7)$ & $578(13.2)$ \\
\hline School & $18(7.1)$ & $24(9.4)$ & $60(23.6)$ & $43(16.9)$ & $52(20.5)$ & $26(10.2)$ & $31(12.2)$ \\
\hline Shop & $23(18.4)$ & $14(11.2)$ & $17(13.6)$ & $0(0.0)$ & $19(15.2)$ & $12(9.6)$ & $40(32.0)$ \\
\hline Haveli & $18(4.2)$ & $19(4.5)$ & $7(1.6)$ & $9(2.1)$ & $20(4.7)$ & $302(71.1)$ & $50(11.8)$ \\
\hline $\begin{array}{l}\text { Medical } \\
\text { centre/hospital }\end{array}$ & $5(7.0)$ & $8(11.3)$ & $8(11.3)$ & $12(16.9)$ & $16(22.5)$ & $10(14.1)$ & $12(16.9)$ \\
\hline Police station & $2(7.7)$ & 0 & $13(50.0)$ & $5(19.2)$ & $1(3.8)$ & $1(3.8)$ & $4(15.4)$ \\
\hline Field/Jungle & $172(8.4)$ & $148(7.2)$ & $225(11.0)$ & $211(10.3)$ & $534(26.1)$ & $383(18.7)$ & $372(18.2)$ \\
\hline Street & $68(5.0)$ & $76(5.6)$ & $165(12.2)$ & $148(10.9)$ & $199(14.7$ & $414(30.5)$ & $287(21.1)$ \\
\hline Madrassa & 0 & 0 & 0 & 0 & $27(35.1)$ & $13(16.9)$ & $37(48.1)$ \\
\hline
\end{tabular}

\begin{tabular}{|c|c|c|c|c|c|c|c|}
\hline \multirow[b]{2}{*}{ Abuser Categories } & 2010 & 2011 & 2012 & 2012 & 2014 & 2011 & 2010 \\
\hline & \multicolumn{7}{|c|}{ Number of Incidents $\mathbf{n}(\%)$} \\
\hline \multirow[b]{2}{*}{ Acquaintance } & & & 2700 & 1510 & & & \\
\hline & $\begin{array}{c}3964 \\
(23.19)\end{array}$ & $\begin{array}{c}2805 \\
(16.41)\end{array}$ & $\begin{array}{c}2 / 80 \\
(16.26)\end{array}$ & $\begin{array}{c}1548 \\
(9.06)\end{array}$ & $\begin{array}{c}1856 \\
(10.86)\end{array}$ & $\begin{array}{c}2310 \\
(13.52)\end{array}$ & $\begin{array}{c}1829 \\
(10.70)\end{array}$ \\
\hline \multirow{2}{*}{ Stranger } & 728 & 1315 & 2172 & 1067 & 1246 & 829 & 798 \\
\hline & $(8.93)$ & $(16.23)$ & $(26.63)$ & $(13.08)$ & $(15.28)$ & $(10.17)$ & $(9.79)$ \\
\hline Relative & $\begin{array}{c}114 \\
(11.53)\end{array}$ & $\begin{array}{c}388 \\
(39.23)\end{array}$ & $\begin{array}{c}189 \\
(19.11)\end{array}$ & $\begin{array}{c}85 \\
(8.59)\end{array}$ & $\begin{array}{c}60 \\
(6.07)\end{array}$ & $\begin{array}{c}77 \\
(7.79)\end{array}$ & $\begin{array}{c}76 \\
(7.68)\end{array}$ \\
\hline Incest & $\begin{array}{c}24 \\
(5.33) \\
\end{array}$ & $\begin{array}{c}56 \\
(12.44) \\
\end{array}$ & $\begin{array}{c}144 \\
(32.00) \\
\end{array}$ & $\begin{array}{c}70 \\
(15.56) \\
\end{array}$ & $\begin{array}{c}62 \\
(13.78) \\
\end{array}$ & $\begin{array}{c}72 \\
(16.00) \\
\end{array}$ & $\begin{array}{c}22 \\
(4.89) \\
\end{array}$ \\
\hline $\begin{array}{l}\text { Molvie/ Faith } \\
\text { healer }\end{array}$ & $\begin{array}{c}18 \\
(6.21)\end{array}$ & $\begin{array}{c}30 \\
(10.34)\end{array}$ & $\begin{array}{c}66 \\
(22.76)\end{array}$ & $\begin{array}{c}28 \\
(9.66)\end{array}$ & $\begin{array}{c}43 \\
(14.83)\end{array}$ & $\begin{array}{c}49 \\
(16.90)\end{array}$ & $\begin{array}{c}56 \\
(19.31)\end{array}$ \\
\hline Teacher & $\begin{array}{c}22 \\
(7.61)\end{array}$ & $\begin{array}{c}91 \\
(31.49)\end{array}$ & $\begin{array}{c}38 \\
(13.15) \\
\end{array}$ & $\begin{array}{c}26 \\
(9.00) \\
\end{array}$ & $\begin{array}{c}20 \\
(6.92)\end{array}$ & $\begin{array}{c}55 \\
(19.03) \\
\end{array}$ & $\begin{array}{c}37 \\
(12.80)\end{array}$ \\
\hline Shopkeeper & $\begin{array}{c}3 \\
(8.57) \\
\end{array}$ & 0 & 0 & 0 & $\begin{array}{c}4 \\
(11.43) \\
\end{array}$ & $\begin{array}{c}12 \\
(34.29) \\
\end{array}$ & $\begin{array}{c}16 \\
(45.71) \\
\end{array}$ \\
\hline Not Mentioned & 0 & 0 & 0 & $\begin{array}{c}110 \\
(11.65)\end{array}$ & $\begin{array}{c}148 \\
(15.68)\end{array}$ & $\begin{array}{c}295 \\
(31.25)\end{array}$ & $\begin{array}{c}391 \\
(41.42)\end{array}$ \\
\hline Jirga & 0 & 0 & 0 & $\begin{array}{c}15 \\
(28.30)\end{array}$ & $\begin{array}{c}8 \\
(15.09)\end{array}$ & $\begin{array}{c}30 \\
(56.60)\end{array}$ & 0 \\
\hline
\end{tabular}


- issue because it is a challenge for societal values and a sign of abnormality in our moral standards.

- Incidents of CSA are a violation of the basic rights of children. The government should introduce special courts to address cases of child sexual abuse at district levels. Moreover, severe and swift punishment will be helpful to create a deterrence against CSA in the community.

- The government, as well as non-governmental organizations and health departments, should introduce courses for the people who are directly involved, from treatment programmes to the investigation of victims of CSA.

- The government, as well as non-governmental organizations and civil society, should launch awareness campaigns for parents to sensitize and educate them on the prevalence of CSA.

\section{References}

1. Hillis S, Mercy J, Amobi A, Kress H. Global prevalence of past-year violence against children: a systematic review and minimum estimates. Pediatrics. 2016; 137(3):e 20154079. Doi: 10.1542/peds.2015-4079

2. Mercy JA, Hillis SD, Butchart A, Bellis MA, Ward CL, Fang $X$, et al. Interpersonal violence: global impact and paths to prevention. Injury Prevention and Environmental Health. 3rded. 2017.

3. Johnston $H$. The Bravehearts Toolbox for Practitioners: working with Child Sexual Assault. $2^{\text {nd }}$ ed. 2014.

4. Tshabalala T, Khosa MT. Awareness of Various Forms of Child Abuse: Pupils' Attributions-A Case Study of Gomadoda Cluster. AJSSMS. 2014; 1(1): 23-8.

5. Taylor C, Steward W. Women and child abuse. London: Hertman (Pvt) Ltd. 2011.

6. PaolucciEO, Genuis ML, Violato C. A meta-analysis of the published research on the effects of child sexual abuse. J Psychol. 2001; 135(1): 17-36. Doi: 10.1080/00223980109603677.

7. Venkateswarlu D, Kasper J, Mathews R, Reis C, lacopino V, Wise $P$. Child labour in India: a health and human rights perspective. The Lancet. 2003; 362: s32-3.

8. Hosin AA. Responses to traumatized children: Springer; 2007.
9. Gorey KM, Leslie DR. The prevalence of child sexual abuse: Integrative review adjustment for potential response and measurement biases. Child Abuse Negl. 1997; 21(4): 391-8. Doi: 10.1016/S0145-2134(96) 00180-9

10. Krug EG, Mercy JA, Dahlberg LL, Zwi AB. The world report on violence and health. Lancet. 2002; 360(9339): 1083-8. Doi: 10.1016/S0140-6736(02) 11133-0

11. Khoso A, Yew VW. Recognizing invisible structural violence on juveniles: A case of Pakistan. Mediterr J Soc Sci. 2015; 6(4): 141. Doi:10.5901/mjss.2015. v6n4s3p141

12. Oyemade AD. Child abuse and neglect: a global phenomenon. Afr J Med Med Sci. 1991; 20(1): 5-9. PMID: 1905471

13. Kisanga F, Mbwambo J, Hogan N, Nystrom L, Emmelin $M$, Lindmark $G$. Perceptions of child sexual abuse $-A$ qualitative interview study with representatives of the socio-Legal system in urban Tanzania. J child sex abuse. 2010; 19(3): 290-309. Doi: 10.1080/10538 711003789031

14. Veenema TG, Thornton CP, Corley A. The public health crisis of child sexual abuse in low- and middleincome countries: an integrative review of the literature. Int J Nurs. 2015; 52(4): 864-81. Doi: 10.1016/j.ijnurstu.2014.10.017

15. Smith K, Bryant-Davis T, Tillman S, Marks A. Stifled voices: barriers to help-seeking behavior for South African childhood sexual assault survivors. J child sex abuse. 2010; 19(3): 255-74. Doi: 10.1080/105387 11003781269

16. Meursing K, Vos T, Coutinho O, Moyo M, Mpofu S, Oneko O, et al. Child sexual abuse in Matabeleland, Zimbabwe. Soc Sci Med. 1995; 41(12): $1693-704$. Doi: 10.1016/0277-9536(95)00130-Y

17. Verelst A, De Schryver M, Broekaert E, Derluyn I. Mental health of victims of sexual violence in eastern Congo: associations with daily stressors, stigma, and labeling. BMC Women's health. 2014; 14(1): 106. Doi: 0.1186/1472-6874-14-106

18. Fontana VJ. Introduction-The Maltreatment Syndrome of Children. Pediat Ann. 1984; 13(10): 736.

19. James $M$. Child abuse and neglect [Series of two parts] Part 1: Redefining the issues. Trends and Issues in Crime and Criminal Justice/Australian Institute of Criminology. 2000; 146: 1. 
20. Tang CS. Childhood experience of sexual abuse among Hong Kong Chinese college students. Child Abuse Negl. 2002; 26(1): 23-37. Doi: 10.1016/S01452134(01)00306-4

21. Kellogg $\mathrm{N}$. The evaluation of sexual abuse in children. Pediat. 2005; 116(2): 506-12. Doi: https://doi.org/10. 1542/peds.2005-1336

22. Finkelhor D, Turner HA, Shattuck A, Hamby SL. Prevalence of childhood exposure to violence, crime, and abuse: Results from the national survey of children's exposure to violence. JAMA pediatr. 2015; 169(8): 746-54. Doi: 10.1001/jamapediatrics.2015. 0676

23. Sharma BR, Gupta M. Child abuse in Chandigarh, India, and its implications. J Clin Foren Med. 2004; 11(5): 248-56. Doi: 10.1016/j.jcfm.2004.01.009

24. Csorba R, Tsikouras P, Lampé R, Póka R. The sexual abuse of female children in Hungary: 20 years' experience. Arch Gynecol Obstet. 2012; 286(1): 161 6. Doi: 10.1007/s00404-012-2282-x

25. Davies EA, Jones AC. Risk factors in child sexual abuse. J Forensic Leg Med. 2013; 20(3): 146-50. Doi: 10.1016/j.jflm.2012.06.005

26. Zhai F, Gao Q. Child maltreatment among Asian Americans: Characteristics and explanatory framework. Child Maltreat. 2009; 14(2): 207-24. Doi: 10.1177/1077559508326286

27. London K, Bruck M, Ceci SJ, Shuman DW. Disclosure of child sexual abuse: What does the research tell us about the ways that children tell?. Psychology, Public Policy, and Law. 2005; 11(1): 194. Doi: 10.1037/10768971.11.1.194

28. Wyatt GE, Loeb TB, Solis B, Carmona JV, Romero G. The prevalence and circumstances of child sexual abuse: Changes across a decade. Child Abuse Negl. 1999 Jan 1;23(1):45-60. Doi: 10.1016/S01452134(98)00110-0

29. Finkelhor D, Ullmann E, Hilweg W. Childhood and Trauma: Separation, Abuse, War. 1999.

30. Finkelhor D. Child sexual abuse: Challenges facing child protection and mental health professionals. Childhood and Trauma: Routledge; 2019. p. 101-16.
31. Smallbone S, Wortley RK. Child sexual abuse in Queensland: Offender characteristics and modus operandi: Queensland Crime Commission and Queensland Police Service Brisbane, Australia; 2000.

32. Organization $\mathbf{W H}$. Preventing child maltreatment: a guide to taking action and generating evidence. 2006.

33. Snyder HN. Sexual assault of young children as reported to law enforcement: Victim, incident, and offender characteristics: DIANE Publishing; 2010.

34. Muhammad T, Zafar N, Raghuvanshi A. Situtational analysis report on prostitution of boys in Pakistan (Lahore and Peshawar). Bangkok: ECPAT International in collaboration with Pakistan Pediatrics Association. 2006.

35. Reproductive A. Sexual Health: An Explorationof Trends in Pakistan. Pakistan Voluntary Health and Nutrition Association (PAVH NA). 2000..

36. Srivastava $R$, Seth $R$, Van Niekerk J. Child abuse and neglect: Challenges and opportunities: JP Medical Ltd; 2013.

37. Maiti KD. Ministry of Women and Child Development, Government of India. Retrieved from January. 2016.

38. Mehnaz A. Child Abuse in Pakistan-Current Perspective. NJHS. 2018;3(4):115.

39. Kane J. Sold for sex: Arena; 1998.

40. Tufail M. Commercial Sexual Exploitation of Children: a situation analysis of Pakistan. Save the Children Sweden. 2005.

41. Fathalla MF. The girl child. Int J Gynaecol Obstet. 2000;70(1):7-12. Doi: 10.1016/S0020-7292(00)00219 $-8$

42. Frederick J. Sexual abuse and exploitation of boys in South Asia: A review of research findings, legislation, policy and programme responses. 2010.

43. Fergusson DM, Horwood LJ, Lynskey MT. Childhood sexual abuse and psychiatric disorder in young adulthood: II. Psychiatric outcomes of childhood sexual abuse. J Am Acad Child Adolesc Psychiatry. 1996; 35(10): 1365-74. Doi: 10.1097/00004583199610000-00024. 